\title{
Editorial: Marketing and finance must agree a common measurement framework
}

Impending dot.com meltdown is giving an added urgency to the need for better tools and measures. In the first eight months of this year a staggering $£ 150 \mathrm{bn}$ was wiped off the value of the UK's leading industrial companies, and disappeared into the black hole of cyberspace. But today the number of cyberfailures is mounting and there is growing emphasis among sophisticated investors about the need for better predictions about the future of cyberspace.

Financial accountants over the past decade have made concessions to institutional investment analysts and fund managers by introducing economic indicators such as Economic Value Added (EVA) and Market Value Added (MVA) alongside the conventional accounting figures. They have done so in company reports and analyst briefings because they need to demonstrate that top management makes economically sophisticated use of invested capital. This has not been an intractable problem for many accountants, as it has only involved minor reworking of familiar accounting spreadsheets. Analysts and fund managers are now pressing for further concessions - disclosure of value drivers, and in particular customer and competitive predictions. This will be comparatively harder.
Management accountants over the past decade have driven up internal efficiency using techniques like Activity Based Costing (ABC) and Enterprise Resource Planning (ERP). They have become better at using non-financial reporting-data to provide balanced scorecards, and early warning indicators about future performance problems. Now they have started examining marketing efficiency. Lord Leverhulme's old saw, 'I know that half of my advertising is wasted, trouble is I don't know which half, is buzzing in many management accountants' heads.

Cranfield School of Management has established the MVA best practice research club with the aim of becoming an internationally recognised centre of excellence in addressing these issues. Although the centre was only established this year, the club's leaders (visiting Professor Robert Shaw and Professor Malcolm McDonald) have been researching marketing measurement and planning since the 1980s. Questions that we are addressing include: What are the best measures to use? How should measurement systems be designed? How should they be implemented? The club has been sponsored by accountants and also marketing managers, and it represents 
a pooling of knowledge of best practice from both fields. This article sets out some of our findings.

\section{FORCES OF CHANGE}

Institutional investment analysts and fund managers tend to be quite sophisticated and understand the importance of economic indicators, whereas the retail investors and brokers tend to focus on Earnings per Share (EPS) and quarterly results. But they do not just look at the internal factors. "Clearly we put an emphasis on non-financial indicators. We look at everything. In an analysis we look at financial and strategic issues and use all of this information to assess the quality of the business' comments Francois LangladeDemoyen, a London based partner of Buttonwood Capital in a recent research study.

The main reason why analysts are interested in customer and competitive data is to improve predictions about demand. They aim to take an objective view, using highly sophisticated predictive models of customers and competition to predict the likely outcomes of company strategy. As a consequence of discussions with their accounting counterparts, analysts are expressing growing concern about the lack of sophistication of the predictive modelling used inside organisations by financial strategists.

Accountants tend to be only peripherally involved in predicting demand, mainly in connection with annual budgeting. When it comes to the predictions needed for financial strategy, accountants are relatively unsophisticated compared to their investment analyst counterparts. It has been widely reported that too often financial strategy gets wrapped up with the 'ego' of the deal-makers, regardless of uncertainties about growth and value creation. Accountants in the past have tended to be passive beancounters to the corporate dreamers. This passivity is set to change, as accountants learn how to use predictive modelling to pop the assumptions of the corporate dreamers.

Another set of forces is driving management accountants to become more involved with customer and competitor measurement. The search for improved efficiency in areas such as manufacturing and logistics has yielded all it can, and so other areas for improvement are being sought: marketing is high on this agenda. The computer industry's CRM revolution is raising investment appraisal issues which management accountants are seeking to address. Balanced scorecard projects that have proved effective in operational areas are running into difficulty in marketing, and consequently management accountants are seeking deeper insights into the objectives and performance goals of marketing. These and other factors are encouraging management accountants to take the lid off marketing.

Accountants are set to embrace changes beyond the ABC and EVA of the last decade. For some these changes 
will occur piecemeal, and knowledge of customers and competition gained in one area will not shared with other areas. However, some accountants take a more ambitious, integrated approach, seeing these changes as part of their broadening role as information and knowledge managers. To see how this could occur, the next section looks at the tools and measures needed.

\section{EMERGING TOOLS AND MEASURES}

Some accountants point out that we will always be partially ignorant about customers and competitors, and argue that measurement is futile. However, having examined many tools and measures we believe that total ignorance is inexcusable, and that partial knowledge of customers and competitors can provide significant benefits. Like all tools, the secret is to know their strengths and weaknesses. Technological advances have contributed a great deal to the success of these new approaches. Without IT the effort of implementing the concepts would have been impossible. Tools for analysing and modelling are commonplace, as are databases.

Two distinct areas require better tools and measures. Investor relations is the first. Information is needed for many occasions: annual reports, press releases, quarterly and monthly reports, analyst briefings, conference calls between external analysts and in-house analysts.

Business units also require better tools and measures. They need tools to appraise market entry and exit decisions, new brand and product launches, where these issues are too detailed to warrant the attention of the main board. Shared resource decisions CRM, call centres, eBusiness - also need to be appraised. Monitoring and control tools are also needed below board level to track the implementation of business unit and shared resource decisions.

Although piecemeal implementation of tools and measures is an option, Cranfield's work suggests that an integrated framework for board and business unit level offers a better approach. We also distinguish between the tools needed to package and interpret measurements, and the measurement data themselves. Both tools and data have to be effective, but choosing the right tools is a prerequisite to choosing the right data.

Predictive modelling is a key tool for making effective decisions to win competitive wars and harness customer potential. This goes beyond trend extrapolation, which has been the mainstay of forecasting used for budgeting. Predicting the outcome of alternative levels of marketing expenditure and mix is vitally important in growth markets. We have built up a best-practice database showing how companies use these tools.

As an example, a major insurance company has developed 'market dynamics models' to predict how customers and competitors will respond. Managers had previously used 'rules of thumb' to support their plans. 
The models allowed the rules of thumb to be validated and calibrated. Checking their plans using these models disclosed inconsistencies and invalid assumptions, and led them to a more rigorous set of plans. The models showed limits to growth, as markets became saturated, and led to revisions of their previous spreadsheet based plans.

Early warning indicators (EWIs) are another outcome of this approach. EWIs are measures that provide advance warning of future events and trends, where remedial action is needed in advance. Market dynamics models help identify areas of significant risk and uncertainty, where EWIs are needed. For example, the insurance company began to develop an early warning system based on its predictive models. These EWIs are conceptually similar to Kaplan and Norton's 'lead indicators'. ${ }^{1}$ However EWIs are based on downside risks, not the upside success factors favoured in the balanced scorecard.

\section{CHANGES INSIDE AND OUTSIDE ACCOUNTING}

The need for these tools and measures appears to be increasing. But who should be responsible for them?

More conservative accountants are kept busy just keeping the books and preparing annual returns and reports. All the above customer and competitor data go beyond what a conservative accounting department can manage.

Cranfield studies of the state of organisations today indicate that the majority have not centralised these customer and competitive measurements or tools. Unlike accounting data, which are consolidated for statutory reasons, customer and competitive data are usually scattered across departments and business units, and measured according to a variety of different standards. As a consequence, the data are not in a suitably reliable state to be disclosed to outside investment analysts. Market research and customer satisfaction surveys are sometimes centralised in a marketing department, but even then they are often found to be inconsistent and incompatible.

Some finance directors have used consultants to develop a measurement framework, which includes packaging of non-financial information for board meetings and investor relations. The measurement framework can also cascade down to lower levels in organisations, and efforts are made to align measures to assure their consistency and objectivity.

Other finance directors have assigned an experienced accountant to work in marketing, and obtain the necessary customer and competitive data. Such titles as marketing controller, and marketing information manager are used for such positions. However, this approach also raises issues of departmental loyalty and accountability.

More progressive finance directors are driving towards a more integrated framework. They have taken on the customer and competitive measurement problem themselves, something which entails creating several new 
roles. Market research is moved into the finance department, thus guaranteeing a degree of objectivity not found when marketing runs MR. Predictive modelling also gets commissioned by the finance department, either by using outside consultants or in-house analysts. Balanced scorecards are developed by the finance department: marketing objectives and strategies thus are quantified in ways that are rare when marketing are responsible for marketing plans.

An encouraging observation of Cranfield seminar attendance is the extent to which internal finance and marketing functions are moving closer. Accountants are keen to understand better the dynamics of competition and customer behaviour. Marketers have learned and use financial language and disciplines. New tools and measures are being embraced.
Irrespective of who is responsible for change, change seems inevitable. Boards of companies have no good excuse to withhold customer and competitor measures from investment analysts, even though there is no statutory requirement. They owe it to their business unit managers to provide measurement frameworks that will do for customers and competition in the next decade what ABC and ERP did for manufacturing and the supply chain in the last decade.

ROBERT SHAW

Managing Editor, Visiting Professor Cranfield School of Management February, 2001

\section{REFERENCE}

1 Kaplan, R. and Norton, D. (1996) 'The Balanced Scorecard', HBS Press. 